\title{
Opiskelijapalautteen kerääminen ja hyödyntäminen opetuksen kehittämisessä
}

\author{
MARI MARTINMAA
}

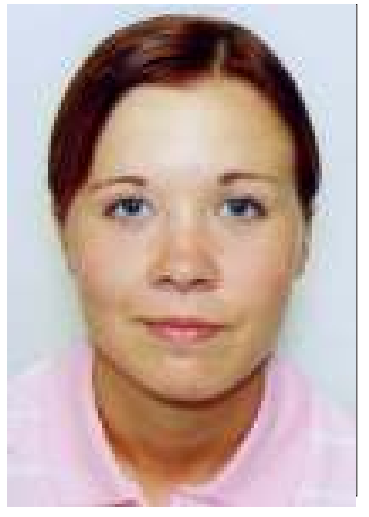

Artikkelissa kiinnostuksen kohteena on opiskelijapalautteen kerääminen ja sen hyödyntäminen opetuksen kehittämisessä. Pohdin Teknillisen korkeakoulun opettajien ja opiskelijoiden kokemuksia opiskelijapalautteen keräämisestä ja sen hyödyntämisestä sekä näiden kokemusten eroja ja yhtäläisyyksiä kyseisen kohderyhmän osalta. Opiskelijat haluaisivat saada nykyistä enemmän tietoa opiskelijapalautteen hyödyntämisestä suorittamillaan kursseilla. Opettajista suurin osa koki, että palautteen hyödyntämiseen sisältyy ongelmia.
Y

liopistoissa ja korkeakouluissa pidetään ehkä itsestään selvänä asiana, että opiskelijoilta tulee kerätä palautetta opetuksesta opetuksen kehittämiseksi. Useassa yliopistossa opiskelijapalautteen hyödyntäminen on tullut myös ajankohtaiseksi haasteeksi muun muassa yliopistojen laadunvarmistusjärjestelmien auditointien yhteydessä. Opiskelijapalautteesta on muodostunut viimeisen kymmenen vuoden aikana tärkeä työkalu opetuksen kehittämiseksi, mutta tutkimustietoa siitä miten opiskelijapalautetta kerätään ja miten tämä palaute vaikuttaa opetuksen kehittämiseen ja laatuun, on vielä varsin vähän saatavilla. Opiskelijapalautetta kerätään moniin eri tarkoituksiin: opettajat keräävät palautetta, jotta he voivat kehittää opetustaan, mutta he käyttävät palautetta myös kuvaamaan omaa pedagogista osaamistaan opetusportfolioissa. Tällä tavoin käytettynä palaute tukee myös viran hakemista, virassa pysymistä ja siinä ylenemistä. Opiskelijapalautetta käytetään myös antamaan tietoa kursseista ja opiskelusta tuleville opiskelijoille. Palautetta myös kerätään useilla eri tavoilla ja eri tahojen tarpeita palvelemaan. Opettajien lisäksi opiskelijapalautetta kerätään joko laitoksen tai tiedekunnan toimesta kun tavoitteena on systemaattisesti selvittää laitoksen tai tiedekunnan opetuksen yleinen taso tai tutkinnon laatu. Systemaattisen palautteen keräämisen lisäksi tapahtuu paljon myös epävirallista ja satunnaista palautteen saamista. Opettajat esimerkiksi saavat palautetta luokkahuoneen sisä- ja ulkopuolella satunnaisina kommentteina, opettajien ja opiskelijoiden järjestämissä tapaamisissa ja kyselyiden kautta. Opiskelijapalaute on tarkoituksenmukaista kerätä kurssin päätyttyä, kun kiinnostuksen kohteena on opiskelijoiden kokemus koko kurssista (Richardson, 2005, 403). Narasimhan (2001) toi kuitenkin esiin, että opiskelijapalautteen kerääminen kurssin lopussa ei hyödytä palautteen antaneita opiskelijoita. Aikaisemmin kerätyllä palautteella on välittömämpi vaikutus. (Narasimhan, 2001.) Palautteen kohteena voivat olla opettajat, kurssit, tutkinto-ohjelmat, laitokset ja tiedekunnat. Useimmissa tutkimuksissa palautetta on kerätty opiskelijoiden havainnoista, joita he ovat tehneet saamastaan opetuksen laadusta tai laajemmin heidän tutkintonsa akateemisesta laadusta. (Richardson, 2005, 401-402.)

Tämän artikkelin alussa pohdin opiskelijapalautteen keräämisen ja hyödyntämisen käytäntöjä aikaisempien tutkimusten valossa. Tämän jälkeen kuvaan tutkimusprosessin. Tutkimusprosessista 
siirryn tulosten esittämiseen. Lopuksi pohdin opiskelijapalauteprosessin nykykäytäntöjä ja niiden kehittämiskohteita.

\section{Opettajien ja opiskelijoiden antama opiskelijapalaute}

Yliopistot keräävät tietoa opiskelijoiden kokemuksista. Tässä kuvatussa tutkimuksessa opettajan antamalla palautteella ymmärretään opettajan opiskelijoille antamaa palautetta heidän kurssilla suoriutumisestaan. Opiskelijapalautteella ymmärretään opiskelijoiden antamaa palautetta opettajan tavasta opettaa, opetusjärjestelyistä ja kurssisisällöstä.

Moilanen ja kumppanit (2008) totesivat artikkelissaan, että opiskelijapalautteen keräämisellä pyritään saamaan opiskelijoiden ääni kuuluviin. Opettajat saattavat kokea palautteen keruun pakkona, eivät keinona kehittää opetusta. Opiskelijapalautteen kerääminen voi myös toimia suojautumisvälineenä muutospaineilta. Tämä tarkoittaa, että opettajat voivat luoda kuvitelman siitä, että opetuksen laadun kehittäminen on järjestyksessä. Tällöin opettajien ei tarvitse kyseenalaistaa perustavia pedagogisia sitoumuksiaan. (Moilanen, Nikkola ja Räihä 2008, 19.)

Opiskelijapalaute on osa systemaattista opetussuunnitelmatyötä ja opetussuunnitelmaa pyritään kehittämään palautteen keräämisen avulla. Yksittäisestä kurssista annettu palaute on osa koko oppiaineen, koulutusohjelman, laitoksen tai tutkinnon laadunvarmistusjärjestelmää. Tämän vuoksi palaute tulisi suunnitella ja käsitellä yhteisöllisesti ja strategisesti, mutta kuitenkin tässä tutkimuksessa fokus on siinä, mitä opiskelijat ja opettajat ymmärtävät palautteen merkitsevän.

\section{Opettajien hyödyntämä opiskelijapalaute}

Opettajat tavallisesti lukevat palautteet, mutta eivät aina muuta opetustaan, vaikka vuosittain puututtaisiin samoihin asioihin (Moilanen ym., 2008, 15-19, 23). On ristiriitaista kerätä opiskelijoilta palautetta ja tämän jälkeen olla käyttämättä sitä (Harvey, 2003). David Kember ja kumppanit (2002) ovat tuoneet esille, että opiskelijapalautteen vähäiseen hyödyntämiseen on syynä se, että opettajille ei anneta ohjausta opetuksen kehittämiseen ja opetusta ei arvosteta riittävästi suhteessa tutkimukseen. Yhtenä syynä voi myös olla, että nykyään useimmissa yliopistoissa opiskelijapalautteen kerääminen kursseilla on pakollista. Kukaan ei kuitenkaan yleensä valvo, miten palautetta hyödynnetään tai missä määrin sitä hyödynnetään. (Kember, Leung \& Kwan, 2002, 42.)

Ongelmia opiskelijapalautteen hyödyntämisessä saattaa aiheuttaa se, että opiskelijoiden käsitykset ja kokemukset opetuksesta eivät aina vastaa toisiaan. Osa opiskelijoista voi kokea opiskeltavat asiat kiinnostaviksi, kun toiset opiskelijat näkevät kyseiset asiat tarpeettomina. Opiskelijat pitävät myös erilaisista opetustavoista, joten opetusta voi olla haasteellista kehittää opiskelijoiden keskenään ristiriitaisen palautteen perusteella. (Moilanen ym., 2008, 15-18.) Opettajien jättäessä opiskelijapalautteen huomiotta opiskelijat saattavat alkaa suhtautua palautteen antamiseen epäilevästi ja yhteistyöhaluttomasti, mikä ilmenee vastaajakatona ja luottamuksen vähenemisenä arviointikyselyiden vaikuttavuutta ja relevanssia kohtaan (Harvey, 2003; Spencer \& Schmelkin, 2002; McInnis, Griffin, James \& Coates, 2001). Opiskelijat kiinnittävätkin yleensä vähän huomiota palautteeseen (Weaver, 2006; Wojtas 1998). Myös todisteet sille, että opiskelijapalautteen kerääminen johtaisi opetuksen laadun kehittymiseen, puuttuvat (Ramsden, 1992, 227; Richardson, 2005, 400). On todettu, että rutiininomainen opiskelijapalautteen kerääminen ei nosta opetuksen laatua (Kember, Leung \& Kwan, 2002, 42).

\section{Opiskelijapalauteprosessin kehittäminen}

Opiskelijapalauteprosessia voidaan kehittää esimerkiksi käyttämällä Harveyn (2003) esittämää palautekehää (satisfaction cycle) hyödyksi palautteen keruussa. Kyseistä palautekehää käytettäessä on huomioitava, että se on kehitetty anglosaksisessa ympäristössä. Opettajan aloittaessa keräämään palautetta opiskelijoilta, palautekehän ideaa hyödyksi käyttäen, opettaja ensin määrittää esimerkiksi kyselylomakkeen kysymykset, minkä jälkeen hän voi laittaa kyselylomakkeen jakeluun opiskelijoille. Kyselylomakkeen vastausajan päätyttyä opettaja analysoi kyselyn tulokset ja raportoi niistä merkittävimmät. Tämän jälkeen opettaja konsultoi toteutetun prosessin, rakentaa toimintasuunnitelman ja toteuttaa ja arvioi sitä. Lopuksi opettaja antaa palautetta opiskelijapalautteen antaneille opiskelijoille. (Harvey, 2003, 4.) Palautekehä toimii silloin, kun kaikki palautekehän osiot käy- 
dään läpi. Jätettäessä jokin osio huomiotta koko kehän toiminta vaarantuu. Siten palautekehä toimii samansuuntaisesti kuin esimerkiksi linjakas opetus. Myös Pohjoismaissa esimerkiksi Ruotsissa on kehitetty opiskelijapalauteprosessia. Opiskelijoille on annettu vaikuttamismahdollisuuksia tämän prosessin joka vaiheessa ja siitä on saatu myönteisiä tuloksia. Tulevaisuudessa opiskelijapalauteprosessi tulisi nähdä tulevaisuuteen katsovana eikä kontrolloivana. Tätä edistää muun muassa opettajien ja opiskelijoiden kesken aktiivisesti käytävä vuorovaikutus palauteprosessiin liittyvistä kokemuksista ja asenteista avoimessa oppimisympäristössä. (Johansson, 2004.)

Opiskelijoiden oppimista voitaisiin syventää ja edistää käyttämällä rinnakkain formatiivista arviointia ja palautteen antamista opiskelijoille. Formatiivisen arvioinnin käyttäminen mahdollistaa sen, että opiskelijat saavat tietää, kuinka heidän oppimisensa edistyy kurssin aikana. Opettajalta saadun palautteen avulla opiskelijat voivat kehittyä koko kurssin ajan esimerkiksi oppimistehtävästä toiseen. Weaver (2006) toi tutkimuksessaan kuitenkin esiin, että myönteisen opiskelijapalautteen saaminen opettajalta on harvinaista, vaikka opiskelijat kokevat sen saamisen erittäin tärkeäksi ja itseluottamusta nostavaksi. Myönteistä ja kielteistä opiskelijapalautetta tulisi antaa opiskelijoille yhtä paljon, jotta palaute motivoisi opiskelijoita suoriutumaan kurssilla mahdollisimman hyvin. (Weaver 2006, 390.) Formatiivisen arvioinnin käyttäminen ja palautteen antaminen myös opettajalle hänen omasta opetuksestaan voisi johtaa opetustaitojen kehittymiseen ja edistymiseen. Opettajallakin on tarve tietää, kuinka opiskelijoiden oppiminen edistyy kurssin aikana. Opiskelijoilta saamansa palautteen avulla opettajalla on tilaisuus kehittää opetustaan jo kurssin aikana.

Nyt raportoitava tutkimus on Teknillisen korkeakoulun palautekäytäntöjen kehittämishankkeeseen kuuluva tutkimus. Kehittämishankkeen tuloksia olen raportoinut ensimmäisen kerran julkaisussa "Teknillisen korkeakoulun konetekniikan osaston opettajien ja opiskelijoiden kokemukset oppimisen arvioinnista ja palautteesta" (Rautiainen, 2008b). Kehittämishankkeen ensimmäisen tutkimuksen tavoitteena oli selvittää Teknillisen korkeakoulun opettajien ja opiskelijoiden kokemuksia palautteesta ja oppimisen arvioinnista (Rautiainen, 2008a).

Tässä kuvatun tutkimuksen tavoitteena oli tutkia, millaisia kokemuksia Teknillisen korkeakoulun opettajilla ja opiskelijoilla on opiskelijapalautteen keräämisestä ja hyödyntämisestä. Tutkimuksen tavoitteena oli myös kuvata, millaisia eroja ja yhtäläisyyksiä on havaittavissa opettajien ja opiskelijoiden kokemuksissa koskien opiskelijapalautteen keräämistä ja hyödyntämistä.

Aikaisemmissa palautetutkimuksissa, jotka kohdistuvat opiskelijoihin, on tutkittu pääasiassa opettajan antaman palautteen käytäntöjä. Nämä palautteeseen liittyvät tutkimukset painottuvat opettajien käsityksiin ja heidän kirjoittamiinsa palautteisiin. (Weaver, 2006, 379.) Opettajien opiskelijoille antamaa palautetta on tutkittu vähän opiskelijoiden näkökulmasta, kuten myös opiskelijoiden käsityksiä saamansa palautteen arvosta ja sen hyödyllisyydestä (Poulos \& Mahony, 2008, 143). Myös opiskelijoiden palautekäsityksistä ja palautteen myötävaikutuksesta opiskelijoiden oppimiseen ja opetukseen on olemassa vähän tunnettua tutkimusta (Weaver, 2006, 379). Lisäksi opiskelijapalautteen hyödyntämisen tiedottamisesta ei juuri löytynyt tieteellisiä tutkimuksia.

\section{Tutkimusprosessi}

Keräsin tutkimusaineiston ryhmähaastatteluilla ( $\mathrm{N}$ =12) kesän ja syksyn 2007 aikana Teknillisen korkeakoulun palautekäytäntöjen kehittämishankkeen yhteydessä.

Aineistonkeruumenetelmäksi valitsin ryhmähaastattelun, koska pyrin saamaan mahdollisimman monipuolisen kuvan palautekäytännöistä ja oppimisen arvioinnista ryhmän tuottaman keskustelun kautta. Ryhmähaastattelun käyttö oli perusteltua, koska se soveltuu tutkimusasetelmaan, johon kuuluu erilaisten ryhmien välinen vertailu. Ryhmä voi herättää jäsenet muistamaan sellaisia asioita, joita ei yksin muistaisi. (Ks. Hirsjärvi \& Hurme, 2001.) Tässä tutkimuksessa vertailin opettajien ja opiskelijoiden kokemuksia tutkittavasta ilmiöstä. Aineistonkeruumenetelmäksi olisin voinut valita myös yksilöhaastattelun, mutta tutkimuksen tavoitteena oli pyrkiä vertaamaan opiskelijoiden ja opettajien kokemuksia. (Rautiainen, 2008b.)

Neljä kolmen hengen ryhmähaastattelua järjestin Teknillisen korkeakoulun opettajille ja opiskelijoille kesän ja syksyn 2007 aikana. Opettajien ensimmäiseen ryhmähaastatteluun osallistuneista opettajista kaikki oli professoreita. Opettajien toisen ryhmähaastattelun osallistujajoukko oli moninaisempi, sillä osallistujista yksi oli professori, yksi 
lehtori ja yksi opettava tutkija. Haastatelluista kuudesta opettajasta kaikki oli miehiä ja vastaavasti kuudesta opiskelijasta viisi oli miehiä. Ensimmäisessä ryhmähaastattelussa haastatelluista opiskelijoista yksi oli toisen vuoden opiskelija ja kaksi neljännen vuoden opiskelijoita. Toiseen ryhmähaastatteluun osallistui kaksi kolmannen vuoden opiskelijaa ja yksi kuudennen vuoden opiskelija. Opettajien ryhmähaastatteluihin kutsuin eri opintosuuntaryhmien edustajia, koska palaute- ja arviointikäytännöt voivat olla hieman erilaisia eri opintosuuntaryhmissä. Myös opiskelijoiden ryhmähaastatteluihin pyrin saamaan opiskelijoita eri pääaineista ja eri vuosikursseilta. Opettajat yksi ja neljä sekä opiskelijat yksi, kaksi ja kolme olivat samasta yksiköstä. Keskenään samasta yksiköstä olivat myös opettajat kaksi ja kolme sekä opiskelijat neljä ja viisi. Lisäksi opettajat viisi ja kuusi sekä opiskelija kuusi olivat keskenään samasta yksiköstä. Tutkimuksen teon yhteydessä tuli ilmi, että palaute- ja arviointikäytännöt eivät juuri eroa tutkittujen kolmen yksikön välillä. Ryhmähaastatteluihin osallistui myös Teknillisessä korkeakoulussa työskennellyt tutkimusharjoittelija. (Rautiainen, 2008b.)

Ryhmähaastattelut etenivät teemoittain, mutta keskustelun kulku vaikutti siihen, mistä teemasta seuraavaksi keskusteltiin. Kaikki haastatteluteemat käsiteltiin jokaisessa haastattelussa. Ryhmähaastatteluita ei järjestetty strukturoituina, koska ne pyrittiin säilyttämään kohtuullisen vapaamuotoisina ja niissä pyrittiin tuottamaan mahdollisimman monipuolista tietoa tutkittavasta ilmiöstä. Jokainen ryhmähaastattelu nauhoitettiin ja nauhat litteroitiin haastatteluiden jälkeen. Ryhmät keskustelivat oppimisen arvioinnista ja palautteen antamisesta ja saamisesta sekä opiskelijapalautteesta. Tässä artikkelissa analysoidaan opiskelijapalautetta. (Martinmaa, 2008b.)

Tutkimuksen aineiston analyysin toteutin laadullisena sisällönanalyysina. Analyysiyksiköksi valitsin ajatuskokonaisuus. Sisällönanalyysin ensimmäisessä vaiheessa etsin aineistosta ajatuksellisia kokonaisuuksia lukemalla ryhmähaastatteluaineistoa, muodostamalla kokonaiskuva siitä ja poimimalla merkityksellisiä ilmauksia aineistosta. Analyysin toisessa vaiheessa ryhmittelin merkitykselliset ilmaukset ja etsin ja vertailin samanlaisuuksia ja erilaisuuksia. Tämän jälkeen rakensin alakategoriat. Aineiston analyysin viimeisessä vaiheessa muodostin yläkategoriat. (Rautiainen, 2008b.)

Aineiston analyysin käsittely- ja analysointi- vaiheet pyrin kuvaamaan mahdollisimman tarkasti (ks. Mäkelä, 1992, 53-57). Tässä tehtävässä auttoi aineiston järjestäminen useaan kertaan uudelleen, koska siten kyseiset kategoriat tarkentuivat lopulliseen muotoonsa. Poimin aineistosta lisäksi lainauksia analyysin havainnollistamiseksi lukijalle. (Martinmaa, 2008b.)

\section{Tulokset}

\section{Palautteen antamiseen motivointi}

Opiskelijoiden mielestä opiskelijapalautetta kerättäessä opettajan kannattaa käyttää motivointikeinoja, koska ne kannustavat opiskelijoita antamaan opiskelijapalautetta. Tehokkaaksi motivointikeinoksi opiskelijat ovat kokeneet lisäpisteiden annon tenttiin. Myös huono kurssi voi motivoida opiskelijoita palautteenantoon.

"No ainakin ne (lisäpisteet motivoivat antamaan palautetta) tai jos on ihan älyttömän huono kurssi, ni sit ehkä haluu antaa palautetta, et tehkää jotain paremmin. " (Opiskelija $5, \mathrm{R} 2)$

Opettajat sen sijaan kokivat, että opiskelijapalautteen keräämiseen ei pääasiassa tarvitse käyttää motivointikeinoja, koska esimerkiksi suuret opiskelijamäärät takaavat palautteen saannin opiskelijoilta. Opettajat pyrkivät pitämään opiskelijoiden suoritusten arvioinnin ja kurssin arvioinnin erillään, koska heidän mukaansa opiskelijat osoittavat omaa aktiivisuuttaan vastatessaan opiskelijapalautekyselyihin.

"Mä oon ollut kylmästi sitä mieltä, et nää on kaksi eri asiaa, et tentissä arvioidaan osaamista ja kykyä aihealueen tiimoilta ja kurssiarviointi on asia erikseen. Niitä ei mielellään sotkis, että se osoittaa tiettyä aktiivisuutta opiskelijalta, et se vastaa kurssikyselyihin. Se ei mun mielestä (ole) reilua lähteä kurssiosaamista ja -tasoa ja -arviointia sotkee porkkanapalalle." (Opettaja 1, R1)

Toisaalta yksi opettaja toi esiin, että hän antaa lisäpisteitä motivoidakseen opiskelijoita antamaan palautetta.

"Mä oon ainakin yhellä kurssilla käyttänyt sitä, että tentissä saa yhden lisäpisteen." (Opettaja 3, R1)

Opettajat kertoivat myös kannustavansa opiskelijoita palautteen antoon esimerkiksi patistamal- 
la heitä motivoivilla sähköpostiviesteillä.

"Mä oon tehnyt vähän hätistelyhommaa, et mä oon lähettänyt sähköpostiviestejä, että nyt on oiva tilaisuus arvioida kurssia ja kehittää kurssia. Sen avaa sen kyselyn, sinne tippuu yksi ja kaksi (opiskelijapalautetta) ja sitten ei enää tuu, kun sitä voi seurata tavallaan, kuinka niitä vastauksia kertyy. Sit ku lähettää tämmösen sähköpostin ni siihen saa aina jonkun "klöntin”. Ne kun lukee sähköpostia ne opiskelijat, ne voi siinä samalla harpata nettikyselypuolella ja vastata samalta istumaltaan niin se on kyllä. Se ei oo mitään motivointia, rohkaisua. Se on enemmänkin patistelua. Muistakaa se, että siellä on mahdollisuus tyrkyllä ja tarjolla. ”(Opettaja 1, R1)

\section{Opiskelijapalautteen antaminen ja saaminen}

Ryhmähaastattelussa opiskelijat toivat esiin, että opiskelijapalautteen antaminen opettajalle on vaikeaa, koska opettajat eivät tiedota riittävästi palautteen antomahdollisuuksista. He ehdottivat, että opettajien tulisi markkinoida nykyistä enemmän opiskelijapalautteen antomahdollisuuksista.

"Mun mielestä opettajien pitäs olla viel avoimempia ja sanoo, että jos teillä on jotain kurssista, niin tulkaa sanomaan luennoitsijalle. Vaan se, että sanoo, auttaa lähestymään." (Opiskelija 3, R1)

Haastatteluihin osallistuneiden opettajien mukaan opiskelijoiden palautteen antokynnys on alentunut. Opiskelijoiden lähestyttävyyttä on helpottanut esimerkiksi sähköpostitse annettava opiskelijapalautteen antomahdollisuus. Yksi opettaja on kuitenkin väsynyt opiskelijoiden antamaan sähköpostipalautteeseen.

"Kun on sähköposti olemassa, niin lähestyttävyys on yllättävän matala joillekin ihmisille. Mä oon vähän väsynytkin sähköpostipalautteeseen." (Opettaja 6, R2)

\section{Opiskelijapalautteen hyödyntäminen ja kehittäminen}

Haastatteluihin osallistuneiden opiskelijoiden mukaan opiskelijapalautetta tulisi hyödyntää nykyistä enemmän. Opiskelijat motivoituisivat antamaan palautetta tietäessään, että sitä myös hyödynnetään.
"Ainakin se (kehittämiskohde) et kaikilla kursseilla kerättäis palautetta ja sitä hyödynnettäis kurssin kehittämisessä ja hyödyntämisestä informoidaan myös opiskelijoita. Tulee tunne, et sitä (palautetta) hyödynnetään. Seuraavan kerran tekee viel vähän vakavammin palautteen." (Opiskelija 3, R1)

Haastatteluihin osallistuneiden opettajien mukaan opiskelijapalautteen hyödyntäminen ei ole tällä hetkellä systemaattista. Kurssien käytännönjärjestelyihin liittyvää palautetta on hyvät mahdollisuudet hyödyntää, mutta kurssin sisältöä koskevia palautteita on vaikeampi hyödyntää. Opettajien mielestä opiskelijapalautetta hyödynnettäessä on otettava huomioon sekä kurssikokonaisuus että opiskelijoiden toivomien asioiden tärkeys. Opettajat kokivatkin palautteen hyödyntämisen aiheuttavan lähinnä haasteita. Opiskelijapalautteen hyödyntäminen on haasteellista sen vuoksi, että opiskelijat toivovat erilaisia asioita palautteissa, he pitävät erilaisista opetustavoista ja ovat eri tavoilla kiinnostuneita kurssin ydinasioista. Myös Moilanen ym. (2008) ovat todenneet, että opiskelijoiden käsitykset ja kokemukset opetuksesta ovat erilaisia ja opiskelijat pitävät erilaisista opetustavoista. Opettajien mukaan osa palautteista on myös makuasioita, jolloin opiskelijapalautteen hyödyntäminen on kompromissien etsimistä.

"Sit on tietysti paljon ihan makuasioita. Meidänkin kursseilla käy vierailevia luennoitsijoita. Jotkut heistä pitää, jotkut taas ei pidä. Ne menee aikalailla ristiin ne palautteet siltä osin ja myöskin opiskelijoiden kiinnostus kurssin ydinasiaa kohtaan vaihtelee aika paljon, että jollain on ainoa prioriteetti se, että pääsee kurssista mahdollisimman tehokkaasti läpi ja saa pisteet rekisteriin ja joitain taas kiinnostais saada lisätietoja asian tiimoilta. Tuossakin on havaittu aika isoja eroja, et mitä siellä toivotaan. Jotkut asiat on kovin työläitä käytännössä toteuttaa ja jotkut asiat pitää kuitenkin kokonaisuuden kannalta harkita, et mikä on järkevää ja mikä ei."

(Opettaja 4, R2)

Opettajat kertoivat myös, että opiskelijapalautteen hyödyntämistä estävät monet uudistushankkeet, koska ne vähentävät opettajien palautteen hyödyntämis- ja kehittämisvalmiutta sekä -halukkuutta.

"Yks asia mikä kannattaa tässä taukotilanteessa muistaa, on että ollaan viemässä läpi 
tutkintorakenneuudistusta. Sitten on tulossa Aalto-yliopistouudistus ja sitten on työn alla osasto-, tiedekuntarakenteen uudistus, kandidaattiohjelmaan uudistushanke on käynnissä. Sitten hallinnolliset palkkausjärjestelmä-, laatujärjestelmäundistus ja työajan kohdentamisjärjestelmä ja kaikki muut ja (tätä) taustaa vasten nähden niin yleinen halukkuus ja valmius hyödyntää kovin vahvasti palautesysteemiä ja kehittää niin ei ehkä (ole) paras mahdollinen. Se täytys tässä muistaa." (Opettaja 4, R2)

Opiskelijoiden mukaan opiskelijapalautteen hyödyntämisestä tiedotetaan joillain kursseilla sähköpostitse. Opiskelijat kokevat, että toisten opiskelijoiden kurssikokemusten kuulemisesta on hyötyä kurssin suorittamisessa. Muiden opiskelijoiden kurssikokemusten kuuleminen mahdollistaa vertaisarviointien tekemisen kurssista. Opiskelijapalautteen hyödyntämiseen liittyvän tiedottamisen suurena haasteena on, että opiskelijoille ei jaeta tarpeeksi tietoa palautteen hyödyntämisestä heidän suorittamillaan kursseilla. Opiskelijat ovatkin sitä mieltä, että osa opettajista ei käytä opiskelijapalautetta opetuksensa kehittämiseen.

"Välillä tulee vähän fiilis, että kun täyttää opiskelijapalautteita, että ne nyt tekee niitä sen takii, et on pakko. Yliopiston rehtori on sanonut, että kerätkää. Sit ne kerää ja heittää sen jälkeen roskiin. Deletoi sen.” (Opiskelija 3, R1)

Harvey ym. (2003) ovat tuoneet myös esiin, että opiskelijat voivat alkaa suhtautua palautteen antamiseen negatiivisesti opettajien jättäessä opiskelijapalautteen käyttämättä. Opiskelijoiden mielestä opiskelijapalautteen hyödyntämiseen liittyvää tiedotusta voitaisiin kehittää esimerkiksi kokoamalla sitä kurssien kotisivuille ja että opiskelijapalautteen tulisi olla julkinen seuraavan vuoden opiskelijaryhmälle.

"Se vois olla mun mielestä ehkä viel parempi, jos kerättäis kurssin kotisivulle tiedotusta siitä, miten kurssia nyt kehitetään ja millaiseen palautteeseen se pohjautuu.” (Opiskelija 2, R1)

Yksi opiskelija suhtautui kyseiseen asiaan kielteisesti tuoden esiin sen, että julkiset opiskelijapalautteet voivat muokata opiskelijoiden kurssia koskevia ennakko-odotuksia.

" Mä en oo ihan varma siitä, että opiskelijapalautteet pitäs olla kaikkien nähtävillä, koska mulla on ainakin itellä vaikuttanut tosi paljon, et jos joku sanoo tosi vaikee kurssi. Sitten se tar- koittaa, että mä en tuu pääsee sitä läpi.” (Opiskelija 2, R1)

Opettajat tiedottavat opiskelijapalautteen hyödyntämisestä luennoilla tai sijoittavat internet-palautekyselyn yhteenvedon kurssin kotisivuille. Opettajat kertoivat, että opiskelijapalautteen hyödyntämisestä tiedottamisen keskeisenä haasteena on, että opiskelijat eivät usein saa tietoa antamansa palautteen avulla tehdyistä muutoksista.

"Tietysti se (on) ongelma, että vaikka nyt tekis muutoksia, reagoisi niihin palautteisiin ja analysoisi jotain niin muutokset ei taas näy niille tyypeille, jotka palautteen on antanut ja esittänyt. Ei ne tuu uudelleen katsomaan, että onko se nyt muuttunut ja parempi ku ennen." (Opettaja 2, R1)

\section{Opiskelijapalautteen aiheuttama tunnekokemus}

Opiskelijat kokivat opiskelijapalautteen antamisen myönteisenä. He kertoivat kuitenkin antavansa pääasiassa kielteistä palautetta. Opiskelijat nostivat esille, että tulevaisuudessa myönteistä opiskelijapalautetta tulisi antaa nykyistä enemmän. Myös Weaver (2006) on todennut, että opiskelijat kokevat myönteisen opiskelijapalautteen saamisen erittäin tärkeäksi, vaikkakin opettajat antavat harvoin kyseisenlaista palautetta. Opiskelijat toivat ryhmäkeskustelussa myös esiin, että opiskelijoiden antama pieni palautteen määrä voi tarkoittaa, että kurssilla asiat toimivat hyvin.

"On harmi, että annetaan vaan negatiivista palautetta. Tietysti siitä on ehkä enemmän hyötyä, jos antaa negatiivista palautetta, mutta voisi antaa positiivistakin palautetta. Kaikkea ei tosiaan tartte muuttaa."

(Opiskelija 1, R1)

Opettajat kertoivat kokevansa, että opiskelijapalaute on yleensä kielteisten asioiden pohtimista ja niiden raportointia. Opettajien mukaan myönteinen opiskelijapalaute auttaa kuitenkin opettajaa jaksamaan ja motivoi häntä kehittämään kurssia. Tämä palaute voi liittyä esimerkiksi siihen, että opiskelija kertoo oppineensa kurssilla runsaasti tai kokeneensa kurssin mielenkiintoiseksi. Opettajien mielestä heidän saamansa myönteinen opiskelijapalaute vaikuttaa sekä opettajaan että opiskelijoihin. Opettaja pyrkii sen avulla parantamaan omaa työtään suunnitellessaan seuraavan vuoden kurssia ja opiskelijat kokevat opettajan tekemän 
kehittämistyön parempana kurssina.

"Mut tietysti palaute varsinkin, jos se on positiivista, niin sillä on kyllä opettajalle hyvä merkitys. Tuolla kun lukukauden luennoi ja pitää kursseja ja sit jos palaute on, että opin runsaasti tai kurssi oli mielenkiintoinen niin kyllä se on "positiivinen oravanpyörä", että taas seuraavana pimeenä syksynä jaksaa petrata omaa meininkiä ja tekemistä, että se on kahdensuuntaista se yhteistyö. Se on toisaalta opiskelijoille parempana kurssina sitä kautta. Yleensä tulee vaan mietittyä, että opiskelijapalaute on negatiivisten asioiden penkomista ja niiden raportointia ja niiden ikään kuin kiukuttelua." (Opettaja 1, R1)

\section{Pohdinta}

Tutkimuksen tavoitteena oli saada selville opiskelijoiden ja opettajien kokemuksia opiskelijapalautteesta ja opettajan antamasta palautteesta. Tämä on case-tutkimus ja löydökset täytyy asettaa siihen kontekstiin. Tutkimuksen tuloksissa ilmeni eettinen ongelma opiskelijoiden motivoimisessa opiskelijapalautteenantoon, koska osa opettajista antaa lisäpisteitä tenttiin houkutellakseen opiskelijoita antamaan palautetta. Opiskelijat kokevat lisäpisteiden annon tenttiin tehokkaana motivointikeinona opiskelijapalautteen antoon. Opettajat pyrkivät sen sijaan pitämään oppimisen arvioinnin ja kurssin arvioinnin erillään, koska opiskelijapalautteen anto ei edistä kurssiasian oppimista. Toisaalta osa opettajista koki, että opiskelijat eivät anna palautetta, jos heitä ei motivoida. Tämän tutkimuksen tulosten perusteella näyttäisi siltä, että opetuksen kehittämiseen myönteisesti suhtautuvat opettajat saavat helpommin opiskelijapalautetta ilman lisäpisteiden käyttöä. Opettajat pyrkivät sitouttamaan opiskelijoita palautteenantoon joko ulkoisen motivoinnin kuten lisäpisteiden kautta tai sisäisen motivoinnin kuten tuomalla oman aidon kiinnostuksen palautetoimintaan esiin (ks. Bandura, 1977). Ulkoisen motivoinnin vaikutukset ovat yleensä lyhytkestoisia ja sisäisen motivoinnin vaikutukset ovat pitkäkestoisia. Näin ollen opettajien olisi hyödyllistä käyttää sisäisen motivoinnin keinoja kannustaessaan opiskelijoita opiskelijapalautteen antoon. Kiinnostavaa on, että opiskelijat kokivat vaikeaksi palautteen annon opettajille. Opettajat kertoivat sen sijaan kokevansa, että opiskelijoiden yhteydenottokynnys on laskenut.
Pyrittäessä syventämään ja edistämään opiskelijoiden oppimista sekä kehittämään opettajien opetustaitoja opiskelijapalautteen muotoja täytyy kehittää monipuolisiksi ja rakentavaa palautetta sisältäväksi. Tällöin on huomioitava, että opiskelijapalautteen tarkoituksena on tukea opettajia heidän opetustyössään ja auttaa heitä huomaamaan opiskelijoiden näkökulman paremmin. Tavoitteena ei ole pisteyttää ja arvostella opettajia. Tämä tarkoittaa sitä, että opiskelijapalaute ei voi olla esimerkiksi palkan peruste, koska silloin se muuttuu arvosteluksi.

Keskeisenä opiskelijapalautteen antamisen kehittämishaasteena pidän opiskelijapalautteen antamistavan vakiinnuttamista Teknilliseen korkeakouluun ja tulevaan Aalto-yliopistoon, kuten myös muihin Suomen yliopistoihin, joissa ei ole vielä vakiintunutta palautteen antamistapaa. Opiskelijapalautteen antamistavan vakiinnuttaminen mahdollistaa systemaattisen palautteen antamisen yliopistokursseilla. Opiskelijapalautetta ei tulisi kuitenkaan nähdä ainoastaan keräämisen ja antamisen asiana, vaan keskeisenä osana opetussuunnitelmatyötä. Tulevaisuudessa tutkimuksen kohteena olleen yliopiston palautejärjestelmien ytimen olisi keskeistä olla opiskelijan oppimisessa ja sen tukemisessa. Tämän jälkeen on mahdollista arvioida sitä, mikä opiskelijaa auttaa oppimaan tai ehkäisee oppimasta.

Mielenkiintoista on, että opiskelijapalautteen kerääminen on suositeltavaa opettajille tutkimuksen kohteena olleessa yliopistossa, mutta sen hyödyntämistä ei arvioida. Eikö juuri opiskelijapalautteen hyödyntäminen ole keskeistä opetuksen laadun kehittämisen kannalta? Opiskelijapalautteen hyödyntämisen tulisikin olla vähintään yhtä merkityksellistä kuin sen keräämisen. Tämä tarkoittaa esimerkiksi, että suositeltaessa opiskelijapalautteen keräämistä opettajille myös sen hyödyntämistä olisi keskeistä arvioida. Myös David Kemberin ja kumppaneiden (2002) tutkimus todisti, että opiskelijapalautteen kerättyään opettajien tulisi aina analysoida tämä palaute ja hyödyntää sitä opetuksen ja oppimisen kehittämisessä. Näin ei aina tapahdu. Kukaan ei yleensä arvioi sitä, miten palautetta hyödynnetään tai missä määrin sitä hyödynnetään. (Kember ym., 2002.) Kontrollia ei tulisi pyrkiä lisäämään, vaan palautteen hyödyntämisen ymmärtämistä olisi tärkeää tukea ja ohjata.

Opiskelijapalautteen hyödyntämisestä pitäisi aina tiedottaa opiskelijoita, koska siten opiskelijat 
näkevät, miten palautetta on hyödynnetty, mikä motivoi heitä antamaan myös muilla kursseilla palautetta. Palautteen hyödyntämisestä tiedottamisessa ongelmia aiheuttaa se, että opiskelijat käyvät kunkin kurssin ainoastaan kerran, joten he eivät näe opettajien tekemiä muutoksia. Palautteen antaneille opiskelijoille olisi kuitenkin mahdollista tiedottaa annetusta palautteesta esimerkiksi sähköpostin välityksellä. Myös kurssien tulevat opiskelijat ovat kiinnostuneita annetusta opiskelijapalautteesta, joten heitäkin tulisi tiedottaa siitä. Opiskelijapalautteen hyödyntämistä ja siitä tiedottamista pitäisi lisätä yliopistokursseilla. Opettajien olisi erittäin tärkeää hyödyntää erityisesti rakentavaa ja kehittää palautetta, jotta opetuksen laatu olisi mahdollisimman korkea ja kurssit opiskelijoille aidosti kiinnostavia. Saataessa opiskelijapalautteen hyödyntäminen ja siitä tiedottaminen toimiviksi kursseilla niitä tulisi myös jatkuvasti kehittää.

Opettajat ja opiskelijat toivat ryhmähaastattelutilanteissa esiin, että opettajan antama ja opiskelijoilta saatu palaute on yleensä kielteistä. Molemmat osapuolet kuitenkin tiedostivat, että myönteisen opiskelijapalautteen saaminen on hyödyllistä opetuksen ja oppimisen kehittämisen kannalta. Myönteistä opiskelijapalautetta tulisikin antaa nykyistä enemmän opettajille. Myös opettajien pitäisi antaa enemmän myönteistä palautetta opiskelijoille.

Tutkimusta tehdessäni havaitsin, että sana "palaute" on ongelmallinen. Myös Poulos \& Mahony (2008) ovat tuoneet tutkimuksessaan esiin, että palaute (feedback) on monimutkainen ja moniulotteinen ilmiö. Moilanen ym. (2008) ovat todenneet artikkelissaan, että yliopistoissa pidetään usein itsestään selvänä, että kaikki osapuolet ymmärtävät palautteen samalla tavalla. Tällöin palautteen perustoja ei ole ääneen lausuttu ja yhtenäistetty. (Moilanen ym., 2008.) Opettajien ja opiskelijoiden ei pitäisi puhua ainoastaan palautteesta, vaan siitä olisi tärkeää puhua mahdollisimman täsmällisesti. Palautesanaston kuvaa tulisi selkeyttää ja kehittää erityisesti suomalaisessa kontekstissa. Palautesanaston kuvan selkeyttäminen ja kehittäminen mahdollistaisi, että yliopisto-opettajat ja opiskelijat voisivat ymmärtää palautteen samalla tavalla, mikä helpottaisi palautteesta käytävää vuorovaikutusta opettajien ja opiskelijoiden kesken.

Voin tämän tutkimuksen pohjalta sanoa, että tutkimuksen kohteena olleessa yliopistossa palautteen kokonaisprosessin tarkoituksena on kehittää opetusta. Opettajat keräävät palautetta opiskelijoilta pääasiassa kurssien lopuksi. Osalla kursseista palautteen keräämiseen käytetään motivointikeinoja. Opiskelijat antavat palautetta opettajan tavasta opettaa, kurssijärjestelyistä ja kurssien sisällöistä pääasiassa palautekyselyiden ja sähköpostin kautta. Opiskelijoiden ja opettajien antama palaute on yleensä kielteistä. Palautteen saatuaan opettajat saattavat jättää palautteen hyödyntämättä, koska sen hyödyntämiseen sisältyy haasteita ja ongelmia. Palautteen hyödyntämisestä tiedottaminen vaihtelee kursseilla. Osalla kursseista palautteen hyödyntämisestä tiedotetaan sähköpostitse. Useilla kursseilla tällaista tiedotusta ei tehdä. Palautteen kokonaisprosessissa on vielä kehitettävää, mutta tämä kehittämistyö on palkitsevaa, koska sen avulla voidaan parantaa opetusta.

Tämän tutkimuksen luotettavuutta voidaan arvioida uskottavuus, siirrettävyys ja varmuus kriteereiden perusteella (Eskola \& Suoranta 2001). Lisäsin tutkimuksen uskottavuutta esittämällä tehdyt aineiston analyysit muutamille haastatteluihin osallistuneille opiskelijoille ja opettajille mahdollisten virhetulkintojen esille tuomiseksi. Heidän mielestään ryhmähaastatteluaineistosta muodostetut tulkinnat ja tutkimustulokset olivat totuudenmukaisia. Paransin tutkimuksen tulosten siirrettävyyttä yhdistämällä tutkimuksen tulokset muuhun aihepiirin tutkimukseen. Tutkimustulosten siirrettävyyttä heikentää kuitenkin se, että tutkimukseen osallistui vain 12 henkilöä. Tutkimuksen rajoitteena voikin olla sen yleistettävyys. Tutkimuksen yleistettävyyttä rajoittava tekijä saattaa myös olla se, että opettajien ja opiskelijoiden kokemuksia on tutkittu vain kolmen oppiaineen osalta. On kuitenkin muistettava, että tutkimustulosten yleistäminen ei ole kvalitatiivisen tutkimuksen tarkoitus (Eskola \& Suoranta 2001). Lisäsin tutkimuksen varmuutta välttämällä ennakko-oletusten tekemistä tutkittavasta ilmiöstä.

\section{Lähteet}

Bandura, A. (1977). Self-efficacy: towards a unifying theory of behavioural change, Psychological Review, 84 (2), 191-215.

Eskola, J. \& Suoranta, J. (2001). Johdatus laadulliseen tutkimukseen. Tampere: Vastapaino.

Harvey, L. (2003). Student feedback. Quality in Higher Education, 9 (1), 3-20.

Hirsjärvi, S. \& Hurme, H. (2001). Tutkimushaas- 
tattelu. Teemahaastattelun teoria ja käytäntö. Helsinki: Yliopistopaino.

Hounsell, D. (1995). Marking and commenting on essays. Teoksessa M. Foster, D. Hounsell $\&$ S. Thompson (toim.) Tutoring and demonstrating: a handbook. Sheffield: Higher Education Staff Development Agency.

Johansson, M. (2004). Utvärdering i form av medverkan och samverkan. Teoksessa Kursvärdering för studentinflytande och kvalitetsutveckling - en antologi med exempel frän elva lärosäten.Högskoleverkets rapportserie 2004: 23 R. Falköping: Elanders Gummessons AB, 99-104.

Kember, D., Leung, D. \& Kwan, K. (2002). Does the use of student feedback questionnaires improve the overall quality of teaching? Assessment \& Evaluation in Higher Education, 27 (5), 411-425.

McInnis, C., Griffin, P., James, R. \& Coates, H. (2001). Development of the course experience questionaire (CEQ). Melbourne: Faculty of Education, University of Melbourne.

Moilanen P., Nikkola, T. \& Räihä, P. (2008). Opiskelijapalautteen käyttökelpoisuus yliopistoopetuksen kehittämisessä. Aikuiskasvatus, $28(1), 15-24$.

Mäkelä, K. (1992). Kvalitatiivisen analyysin arviointiperusteet. Teoksessa K. Mäkelä (toim.) Kvalitativisen aineiston analyysi ja tulkinta. Helsinki: Gaudeamus, 42-61.

Narasimhan, K. (2001). Improving the climate of teaching sessions: the use of evaluations by students and instructors. Quality in Higher Education, 7 (3), 179-190.

Poulos, A. \& Mahony, M. J. (2008). Effectivenee of feedback: the students' perspective. $A s$ sessment \& Evaluation in Higher Education, $33(2), 143-154$.

Ramsden, P. (1992). Learning to teach in higher education. London: Routledge.

Rautiainen, M. (2008a). Teknillisen korkeakoulun konetekniikan osaston opettajien ja opiskelijoiden kokemukset oppimisen arvioinnista ja palautteesta. Pro gradu -tutkielma. Helsingin yliopisto. Kasvatustieteen laitos. (Artikkelin kirjoittaja, nykyisin Martinmaa)

Rautiainen, M (2008b). Teknillisen korkeakoulun konetekniikan osaston opettajien ja opiskelijoiden kokemukset oppimisen arvioinnista ja palautteesta. Teknillisen korkeakoulun Opetuksen ja opiskelun tuen julkaisuja (1). Julkaisu on saatavana elektronisena osoitteesta: http://opetuki.tkk.fi/p/julkaisut/. (Artikkelin kirjoittaja, nykyisin Martinmaa)

Richardson, J. T. E. (2005). Instruments for obtaining student feedback: a review of the literature. Assessment \& Evaluation in Higher Education, 30 (4), 387-415.

Spencer, K. J. \& Schmelkin, L. P. (2002). Student perspectives on teaching and its evaluation. Assessment and Evaluation in Higher Education, 27 (5), 397-409.

Tuomi, J. \& Sarajärvi, A. (2002). Laadullinen tutkimus ja sisällön analyysi. Helsinki: Tammi.

Weaver, M. R. (2006). Do students value feedback? Student perceptions of tutors' written responses. Assessment \& Evaluation in Higher Education, 31 (3), 379-394.

Wojtas, O. (1998). Feedback? No, just give us the answers. Times Higher Education Supplement.

\section{Lifelong Learning in Europe $\boldsymbol{L} \boldsymbol{L i n} \boldsymbol{E}$}

Tilaa näköala Euroopan aikuiskasvatukseen!

Tarjous Aikuiskasvatuksen tilaajille: Lifelong Learning in Europe -lehden vuosikerta 2009 tai 2010 (4 numeroa) hintaan 30 euroa (norm. 45 euroa).

Teemat 2010: LLL and Social Cohesion; LLL and Wellbeing; Education Tourism \& Travel and LLL; East and West Learning from Each Other. 